\title{
Dorsal Raphe Neuroinflammation Promotes Dramatic Behavioral Stress Dysregulation
}

\author{
Alexis R. Howerton, Alison V. Roland, and Tracy L. Bale \\ Department of Animal Biology, University of Pennsylvania, Philadelphia, Pennsylvania 19104
}

\begin{abstract}
Impulsivity, risk-taking behavior, and elevated stress responsivity are prominent symptoms of mania, a behavioral state common to schizophrenia and bipolar disorder. Though inflammatory processes activated within the brain are involved in the pathophysiology of both disorders, the specific mechanisms by which neuroinflammation drives manic behavior are not well understood. Serotonin cell bodies originating within the dorsal raphe (DR) play a major role in the regulation of behavioral features characteristic of mania. Therefore, we hypothesized that the link between neuroinflammation and manic behavior may be mediated by actions on serotonergic neurocircuitry. To examine this, we induced local neuroinflammation in the DR by viral delivery of Cre recombinase into interleukin (IL) $-1 \beta^{\mathrm{XAT}}$ transgenic male and female mice, resulting in overexpressing of the proinflammatory cytokine, IL- $1 \beta$. For assertion of brain-region specificity of these outcomes, the prefrontal cortex (PFC), as a downstream target of DR serotonergic projections, was also infused. Inflammation within the DR, but not the PFC, resulted in a profound display of manic-like behavior, characterized by increased stress-induced locomotion and responsivity, and reduced risk-aversion/fearfulness. Microarray analysis of the DR revealed a dramatic increase in immune-related genes, and dysregulation of genes important in GABAergic, glutamatergic, and serotonergic neurotransmission. Behavioral and physiological changes were driven by a loss of serotonergic neurons and reduced output as measured by highperformance liquid chromatography, demonstrating inflammation-induced serotonergic hypofunction. Behavioral changes were rescued by acute selective serotonin reuptake inhibitor treatment, supporting the hypothesis that serotonin dysregulation stemming from neuroinflammation in the DR underlies manic-like behaviors.
\end{abstract}

Key words: dorsal raphe; interleukin- $1 \beta$; mania; neuroinflammation; serotonin; stress

\section{Introduction}

Schizophrenia, bipolar disorder, and other psychotic illnesses commonly co-occur with immune dysfunction, where patients exhibit altered cytokine profiles, and postmortem tissue indicates neuroimmunological abnormalities (Müller et al., 2009; Modabbernia et al., 2013). Brain-wide neuroinflammation can impact behavior, including those behaviors that are altered in disease. Chronic brain infection with the parasite Toxoplasma gondii, for example, has a profound ability to increase impulsivity, as well as the incidence of schizophrenia and suicide, even following parasite clearance (Alvarado-Esquivel et al., 2013; Ingram et al., 2013; Webster et al., 2013). Furthermore, there is significant copresen-

\footnotetext{
Received Jan. 7, 2014; revised April 11, 2014; accepted April 15, 2014.

Author contributions: A.R.H., A.V.R., and T.L.B. designed research; A.R.H. and A.V.R. performed research; A.R.H. analyzed data; A.R.H. and T.L.B. wrote the paper.

This work was supported by National Institutes of Health Grant MH073030. HPLC studies were conducted with the support of the Intellectual and Developmental Disabilities Research Center Grant P30HD26979. We thank M.K. $O^{\prime} B a n i o n$ at the University of Rochester for the generous gift of the IL- $1 \beta$ founder mice. We thankE. Krizman and Dr. M.P. Robinson of the Intellectual and Developmental Disabilities Research Center and the University of Pennsylvania Microarray Core for HPLC and microarray contributions. We gratefully acknowledge the contribution of Dr. C.L. Howerton for help with statistical analysis, J.M. Fluharty for technical support, and A.B. Rodgers for editorial assistance.

The authors declare no competing financial interests.

Correspondence should be addressed to Tracy L. Bale, PhD, Professor of Neuroscience, Director, Neuroscience Center SOVM, University of Pennsylvania, 201E Vet, 3800 Spruce Street, Philadelphia, PA 19104-6046. E-mail: tbale@vet.upenn.edu.

DOI:10.1523/JNEUROSCI.0118-14.2014

Copyright $\odot 2014$ the authors $\quad 0270-6474 / 14 / 337113-11 \$ 15.00 / 0$
}

tation of primary immunological disorders with psychiatric symptoms. Notably, patients with synaptic autoimmune encephalitis are commonly first treated following presentation with manic behavior (Rosenfeld and Dalmau, 2011), and the neuropsychiatric manifestations of multiple sclerosis, lupus, and rheumatoid arthritis include irritability, mood swings, distractibility, and impulsivity (Kwentus et al., 1986; Bruce, 2008; Meszaros et al., 2012). Recent studies have highlighted the important role of neuroinflammation as a contributing factor in neuropsychiatric disease (for review, see Najjar et al., 2013).

Animal models have clearly demonstrated the ability of proinflammatory cytokines, such as interleukin (IL)- $1 \beta$, interferon- $\gamma$, tumor necrosis factor- $\alpha$, and lipopolysaccharide, to modulate arousal and coping behaviors when administered peripherally (Dantzer et al., 2008). These same molecules alter discrete aspects of behavior when delivered intracerebroventricularly or acutely into specific brain regions, suggesting that access to and action on particular brain areas may be central to their effects (Song et al., 2006; Huang et al., 2008; Barrientos et al., 2012; Hayley et al., 2013). Brain regions adjacent to sources of CSF, which carries circulating immune cells, may be particularly susceptible to the effects of inflammation (de Vries et al., 1997).

The serotonergic dorsal raphe (DR) is located in apposition to the cerebral aqueduct, making it a potentially vulnerable site for inflammatory insult. Serotonin (5-HT) plays a central role in the 
modulation of arousal, impulsivity, hedonic, and hyperaggressive behaviors, as well as stress responsivity, all of which are central manifestations of mania (Shiah and Yatham, 2000; Crockett et al., 2010). In vitro, neuroinflammatory signaling molecules, including IL- $1 \beta$, alter serotonergic neuron excitability and neurotransmitter release (Manfridi et al., 2003; Zhu et al., 2006). Postmortem tissue and clinical studies of CSF, platelet assessments, and neuroendocrine challenge provide evidence to support the hypothesis that 5-HT deficiency is involved in mania, and that enhancement of 5-HT neurotransmission may exert a mood-stabilizing effect (Shiah and Yatham, 2000). Largely due to the challenge of experimental induction of a relevant inflammatory trigger, however, the mechanism and anatomical specificity by which this occurs remains unknown.

Here, we used an IL-1 $\beta^{\mathrm{XAT}}$ model to induce neuroinflammation with temporal and brain-region specificity (Shaftel et al., 2007a, b; Hein et al., 2010). This model has the advantages of sustained IL- $1 \beta$ overexpression, allowing continuous cytokine production, and of regional specificity, as release in neuronal projection regions or sites of microglial trafficking is prevented through astrocytic-specific production. Using this approach, we tested the hypothesis that neuroinflammation in the serotonergic DR can drive manic-like behavior.

\section{Materials and Methods}

\section{Animals}

The construction and characterization of the IL- $1 \beta^{\mathrm{XAT}}$ line has been described previously (Shaftel et al., 2007a,b). In our studies, IL-1 $\beta^{\text {XAT }}$ male mice on a C57BL/6 background were bred with 129S/J females to create $\mathrm{F} 1$ hybrid mice carrying the IL- $1 \beta^{\mathrm{XAT}}$ transgene. Justification for using a mixed background strain in these studies is related to stressresponsive phenotypes and physiology. C57BL/6 mice are extremely low stress responders, making them a less desirable choice for stress studies. Meanwhile, 129S/J mice are more robust stress responders, but frequently lack a fully formed corpus collusum and can be poor performers in behavioral tests. However, the combination of these two strains produces a hybrid vigor that serves stress research well with consistent responses and behavioral outcomes (McEuen et al., 2008,2009; Gerber and Bale, 2012). Both WT and transgenic littermates were used in initial behavioral studies. Mechanistic follow-up experiments were conducted in transgenic mice only. Because we observed no sex differences in behavior or gene expression, immunofluorescence of the DR was conducted on brain sections from male mice only. Mice were maintained under a $12 \mathrm{~h}$ light/dark cycle with ad libitum access to food and water. All studies were conducted in accordance with experimental protocols approved by the University of Pennsylvania Institutional Animal Care and Use Committee.

\section{Viruses and stereotaxic surgery}

Adeno-associated virus (AAV) vectors were produced and purchased from the University of Pennsylvania Vector Core and injected into 8-10week-old WT or IL- $1 \beta^{\mathrm{XAT}}$ transgenic littermates. Two viruses were used in this study: AAV2/5 containing a transgene for green fluorescent protein (AAV-GFP; AAV2.5.CMV.GFP.WPRE.SV40) and AAV2/5 containing transgenes for both GFP and Cre recombinase (AAV-Cre; AAV2.5.CMV.GFP.Cre.WPRE.SV40). AAV2/5 was used for its greater ability transduce glial cells (Koerber et al., 2009), which we confirmed compared with AAV2/1 and AAV2/9 in pilot studies. Correct infusion placement was verified by visualization of GFP in $300 \mu \mathrm{M}$ sections containing the DR. For viral infusions, mice were anesthetized using isoflurane, before a 33 gauge needle attached to a $10 \mu$ l Hamilton syringe was positioned within the DR using a stereotaxic instrument (Kopf), according to the following coordinates (from brain surface): anteroposterior, $-4.36 \mathrm{~mm}$; mediolateral, $+1.5 \mathrm{~mm}$; dorsoventral, $3.625 \mathrm{~mm}$; angled $26^{\circ}$ (Takahashi et al., 2010). Over the course of $1 \mathrm{~min}, 0.25 \mu \mathrm{l}$ of virus diluted to $1.0 \mathrm{e}^{10} \mathrm{GC}$ with sterile artificial CSF was administered. Based on pilot testing of the time course of viral gene expression, and to allow for ade- quate recovery time, behavioral testing began 5 weeks after. All males were infused within a $3 \mathrm{~d}$ time window, followed by all females, again within a $3 \mathrm{~d}$ time window, 1 week later.

\section{Immunofluorescence}

Six weeks after surgery, animals were perfused with ice-cold PBS followed by $4 \%$ paraformaldehyde. Whole brains were removed, postfixed in $4 \%$ paraformaldehyde overnight, and transferred to $30 \%$ sucrose solution for $48 \mathrm{~h}$. Brains were then removed from solution and stored at $-80^{\circ} \mathrm{C}$ until cryostat sectioning. Tissue was cut on a cryostat into four serial sets of $30 \mu \mathrm{m}$ coronal sections containing the DR, and stored in cryoprotectant ( $30 \%$ sucrose, $30 \%$ glycerol, in PBS) at $-20^{\circ} \mathrm{C}$ until staining. Sections were identified and anatomically matched using the Mouse Brain Atlas (Paxinos and Franklin, 2001). One set of DR sections from each animal was stained in each antibody. TPH-stained sections were first pretreated with a $30 \mathrm{~min}$ incubation in $0.1 \mathrm{~m}$ glycine followed by a 10 min incubation in $0.03 \%$ SDS. All sections were then washed three times in PBS, and incubated in 3\% normal goat serum and $0.25 \%$ Triton X-100 in PBS (NGS-PBST) to block and permeabilize, respectively. Sections were incubated overnight in the appropriate primary antibody (rat antiGFAP at 1:250; catalog \#130300, Invitrogen; sheep anti-TPH at 1:500; catalog \#AB1541, Millipore; mouse anti-NeuN at 1:500; catalog \#MAB377B, Millipore Bioscience Research Reagents) in NGS-PBST. Sections were then washed and incubated for $1 \mathrm{~h}$ in goat anti-rat Alexa 568 fluorescent secondary antibody (1:500; catalog \#A-11077, Rockland Immunochemicals) in NGS-PBST. Slides were mounted with ProLong gold antifade reagent containing DAPI (Invitrogen) to stain nuclei, and then cured at room temperature overnight before image acquisition. Control sections were processed in parallel omitting the primary antibodies. A separate cohort of animals was killed without perfusion to better identify immunological markers, and brains were immediately frozen on dry ice and stored at $-80^{\circ} \mathrm{C}$ until cryostat sectioning. These sections were cut at $10 \mu \mathrm{m}$ directly onto slides, air dried overnight, and then postfixed for $20 \mathrm{~min}$ in ice-cold acetone. Sections were processed for the immunological markers rat anti-CD11b (M1/70, 1:500; catalog \#140112-81, eBiosciences) and rat anti-IDO (1:500; catalog \#122402, BioLegend) as above, omitting any preincubation steps.

Regions of interest were captured using a 10-bit cooled QICam digital camera (QImaging) affixed to a Nikon Eclipse fluorescent microscope at $20 \times$ magnification. Slides for each antibody were captured at a uniform exposure time; however, baseline differences in immunofluroescence between antibodies necessitated different exposure times for different antibodies to remain within linear dynamic range for semiquantification. Semiquantitative fluorescence measurements were made within a defined region of interest to yield a mean intensity value, using IPLabs for Macintosh software (BD Biosciences/Scanalytics). Cell counts for TPHimmunoreactive cells were performed with the aid of CellProfiler, as previously described (Howerton et al., 2013).

\section{LacZ detection}

Four sets of four $30 \mu \mathrm{m}$ sections were made from the DR of six animals, which were perfused 8 weeks following AAV-Cre infusion, and of three animals following AAV-GFP infusion. One set of each was used to assess $\mathrm{LacZ}$ as an indicator of transgene expression (Shaftel et al., 2007a). Sections were collected into cryoprotectant (30\% sucrose, $30 \%$ glycerol in PBS) and stored at $4^{\circ} \mathrm{C}$ until processing. Sections were transferred to PBS the day before LacZ staining, and washed on a rotator overnight. Sections were then transferred to a solution containing $0.1 \% \mathrm{X}$-Gal (5-bromo-4chloro-3-indolyl $\beta$-D-galactopyranoside), $2 \mathrm{~mm} \mathrm{MgCl}_{2}, 5 \mathrm{~mm}$ potassium ferricyanide, and $5 \mathrm{~mm}$ potassium ferrocyanide for $24 \mathrm{~h}$ at $37^{\circ} \mathrm{C}$. Sections were washed twice in PBS, successively dehydrated in 75 , 95, and $100 \%$ ethanol, and left in Citrisolv before coverslipping. Sections were mounted with Permount, and allowed to dry overnight before image acquisition. Images were captured using a 10-bit cooled QICam digital camera (QImaging) at $4 \times$ and $40 \times$. Sections were manually assessed for LacZ-positive cells through visualization of punctate blue staining.

\section{Behavioral testing}

Behavioral testing was performed on mice $(n=6-8)$ beginning 5 weeks after surgery targeting the DR in the following order: elevated plus-maze, 

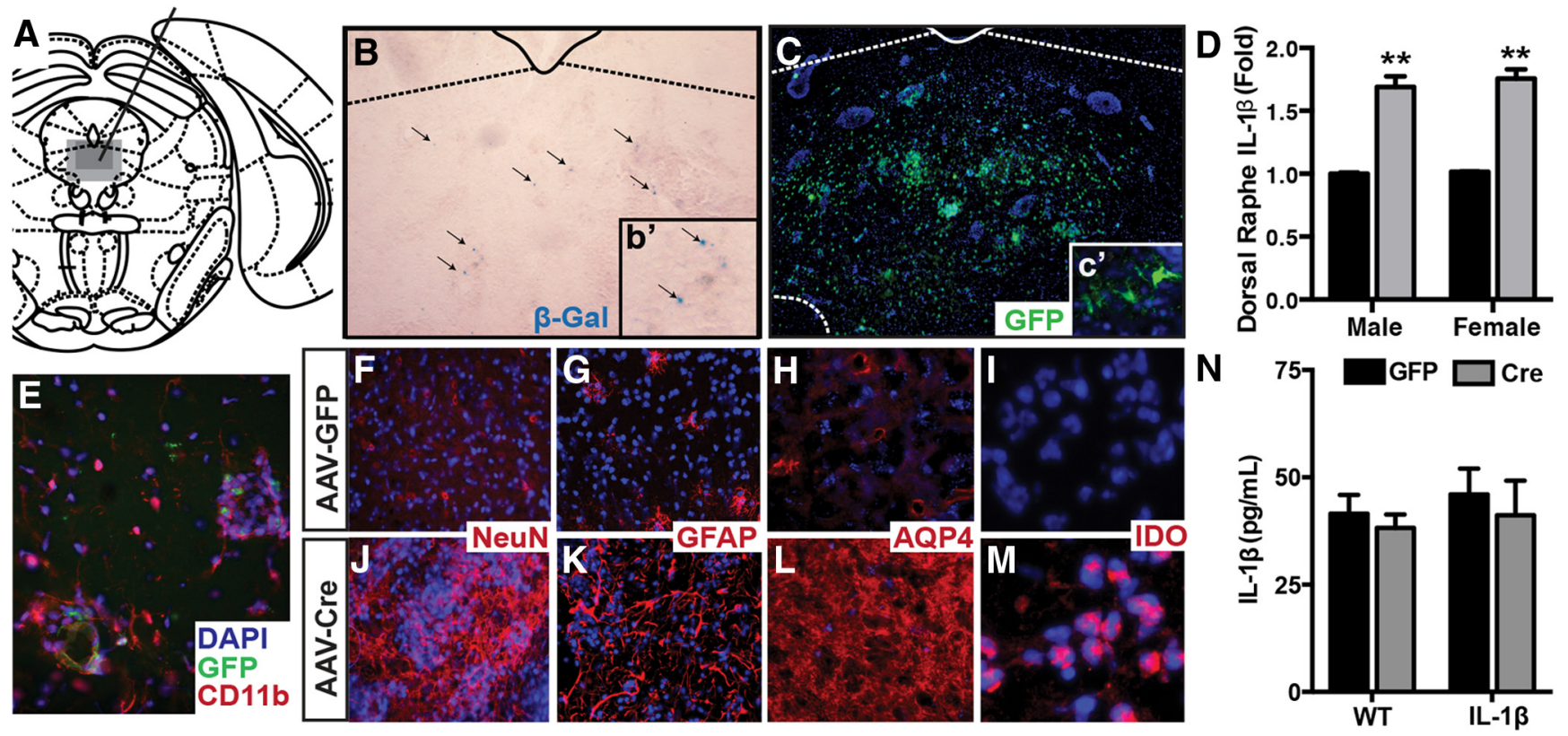

Figure 1. IL-1 $\beta$ overexpression within the DR causes local neuroinflammation. $A$, Location of the DR in the Mouse Brain Atlas (Paxinos and Franklin, 2001). B, C, Representative images highlight spatially restricted $\beta$-Gal $(\boldsymbol{B})$ and GFP immunofluorescence $(\boldsymbol{C})$ following AAV-Cre infusion. $\boldsymbol{b}^{\prime}, \boldsymbol{C}^{\prime}$, Higher magnification of subfield. $\boldsymbol{D}$, AAV-Cre infusion significantly increases IL-1 $\beta$ mRNA in both males and females in the DR. $\boldsymbol{E}-\boldsymbol{M}$, Immunofluorescent characterization of microglia $(\boldsymbol{E}, \mathbf{C D} 11 \mathrm{~b})$ neurons $(\boldsymbol{F}, \boldsymbol{J}$, NeuN), astrocytes $[\boldsymbol{G}, \boldsymbol{K}, \mathrm{GFAP} ; \boldsymbol{H}, \boldsymbol{L}$, aquaporin-4 (AQP4)] and IDO (I, $\boldsymbol{M})$, an enzyme that catabolizes tryptophan in AAV-GFP-infused mice $(\boldsymbol{E}-\boldsymbol{H})$ and AAV-Cre-infused mice $(\boldsymbol{I}-\boldsymbol{L})$. $\boldsymbol{N}$, ELISA of plasma samples reveals no effect of DR AAV-Cre infusion on circulating IL-1 $\beta$. Data are presented as mean \pm SEM, $n=6-7$; ${ }^{* *} p<0.01$ denotes main effect of treatment following two-way ANOVA comparing sex (male vs female) or genotype (WT vs IL-1 $\beta$ ) by treatment (AAV-GFP vs AAV-(re).

light/dark box, hypothalamic-pituitary-adrenal (HPA) axis stress test. A separate cohort was used in the locobox. Behavioral testing on animals infused with virus into the prefrontal cortex (PFC) were tested in the elevated plus-maze and light/dark box followed by an HPA axis stress test. All behavioral testing was performed by an experimenter blinded to mouse genotype and treatment. Males and females were tested in separate cohorts (males, followed by females) to allow testing at equal days postsurgery and to prevent the influence of female odor on male behavior. All behavioral data are therefore presented as within-sex comparisons.

Elevated plus-maze. Mice were placed in the center of the maze facing an open arm at the beginning of the 5 min test. Light intensity in the open arms was 6 lux. All testing occurred 2-5 h after lights-off. Distance traveled and time spent in each arm was analyzed by AnyMaze software. If a mouse fell off the open arm, the test was paused and the animal was placed back in the center of the maze. If the animal fell off the maze more than once, this was noted and that animal was excluded from analysis.

Light/dark box. Mice were placed in the light compartment at the beginning of the $10 \mathrm{~min}$ test session. Light intensity was set at 175 lux in the light compartment. All testing occurred $2-5 \mathrm{~h}$ after lights-off. Total distance traveled, time spent in the light compartment, and transitions between the light and dark compartments were analyzed with ANY-maze v4.75 software (Stoelting). Methods were similar to those described previously (McEuen et al., 2009).

Locobox. The locobox consists of a two-compartment apparatus connected by a $6 \mathrm{~cm}$ throughway. Mice were placed in the center of the wide compartment $(25 \times 27 \mathrm{~cm})$, built to the size of the light compartment of the light/dark box, facing the narrow entry at the beginning of the $10 \mathrm{~min}$ test. The narrow compartment $(8 \times 84.375 \mathrm{~cm})$ lay adjacent to the wide compartment, giving equal floor space to traverse $\left(675 \mathrm{~cm}^{2}\right)$ but in a confined space, similar to the closed arm of the elevated plus-maze. Light intensity in the wide compartment was set at 300 lux. This novel test was used following testing on the light/dark box and elevated plus-maze for several reasons. First, it was used as an additional measure of stressinduced locomotion. Additionally, as equal floor space was given in both the open and closed compartments, it prevented the potential confounding interpretation of choice of side preference (as in the light/dark box).
Last, it tested the possibility that the animals experienced a claustrophobic reaction to the closed compartment of the elevated plus-maze, which would explain their preference for the open arm, rather than differences in risk-taking, general arousal, or anxiety-like behavior. All testing occurred 4-9 h after lights-on. Distance traveled and time spent in each zone were recorded, tracked, and analyzed by AnyMaze software.

\section{HPA axis assessment}

Testing was performed over a $4 \mathrm{~h}$ period beginning $1 \mathrm{~h}$ after lights-on. Ten microliters of tail blood were collected at $0,15,30$, and $90 \mathrm{~min}$. Between 0 and 15 min time points, mice were restrained in a $50 \mathrm{ml}$ conical tube with a $5 \mathrm{~mm}$ air hole. Corticosterone was determined by radioimmunoassay (MP Biomedicals) using $3 \mu \mathrm{l}$ of plasma with a variance coefficient $\left(R^{2}\right)$ of 0.9985 , as previously described (Gerber and Bale, 2012).

\section{Gene expression microarray}

Whole brains from behaviorally tested animals $(n=6-8)$ were cryosectioned at $-20^{\circ} \mathrm{C}$. Using a hollow needle (Ted Pella), three $0.75 \mathrm{~mm}$ punches containing the DR from $300 \mu \mathrm{M}$ slices were micropunched according to the Mouse Brain Atlas (Paxinos and Franklin, 2001). Punches were bath sonicated for $2.5 \mathrm{~min}(30 \mathrm{~s}$ on/off cycles) in TRIzol reagent (Invitrogen). RNA was isolated by RNeasy kit (Qiagen) and suspended in RNase-free water. Total RNA was sent to the University of Pennsylvania Path BioResources Molecular Profiling Core for Affimetrix GeneChip Mouse Gene 1.0 ST analysis.

\section{Quantification of biogenic amines}

Levels of monoamine neurotransmitters were determined using highperformance liquid chromatography (HPLC) as described previously (Stein et al., 2006) with modifications. Animals were killed by rapid cervical dislocation, and brains were dissected and immediately frozen on dry ice to be stored at $-80^{\circ} \mathrm{C}$ until processing. Thereafter, eight $1 \mathrm{~mm}$ punches containing the medial PFC or three $0.75 \mathrm{~mm}$ punches containing the DR from $300 \mu \mathrm{m}$ slices were collected from AAV-GFP-infused and AAV-Cre-infused animals into homogenization buffer $(22 \mathrm{~mm}$ sodium acetate, 75 mm glacial acetic acid, 0.05 mm EDTA, pH 4.95) con- 

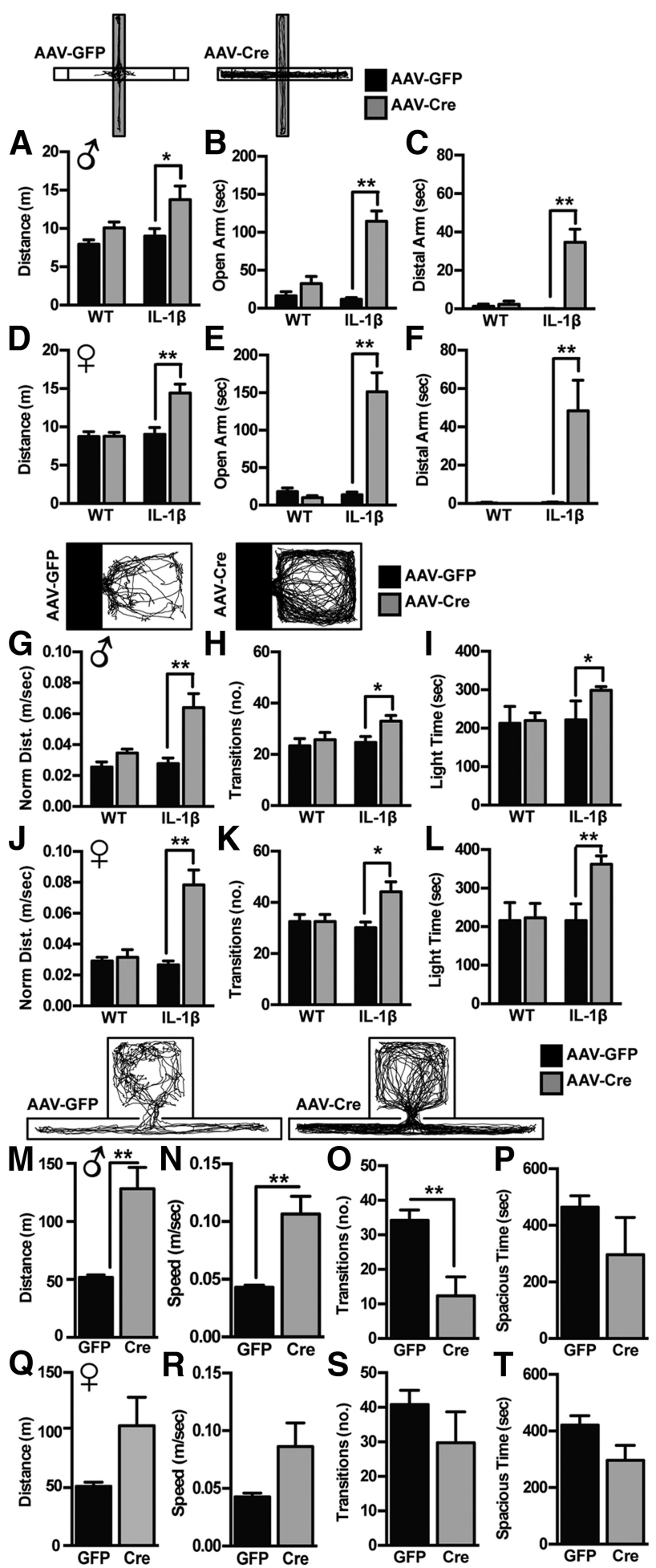

Figure 2. DR neuroinflammation causes manic-like behavior. $\boldsymbol{A}-\boldsymbol{F}$, In the elevated plus-maze, both male $(\boldsymbol{A}-\boldsymbol{C})$ and female $(\boldsymbol{D}-\boldsymbol{F}) \mathrm{IL}-1 \beta^{\mathrm{XAT}}$ mice infused with AAV-Cre display increased locomotion $(\boldsymbol{A}, \boldsymbol{D})$, time in the open $\operatorname{arm}(\boldsymbol{B}, \boldsymbol{E})$, and time in the distal ends of the open $\operatorname{arm}(\boldsymbol{C}, \boldsymbol{F}) . \boldsymbol{G}-\boldsymbol{L}$, In the light/dark box, both male $(\mathbf{G}-\boldsymbol{I})$ and female $(\boldsymbol{J}-\boldsymbol{L}) \mathrm{IL}-1 \beta^{\mathrm{XAT}}$ mice infused with AAV-Cre travel a greater distance in the light compartment (distance, normalized to time spent in light compartment; $\boldsymbol{G}, \boldsymbol{J})$, transition more between light and dark compartments $(\boldsymbol{H}, \boldsymbol{K})$, and spend more time in the light compartment $(\boldsymbol{I}, \boldsymbol{L}) . \boldsymbol{M}-\boldsymbol{P}$, In the locobox, male IL- $1 \beta^{\mathrm{XAT}}$ mice infused with AAV-Cre travel more throughout the test $(\boldsymbol{M})$ at a greater speed $(\boldsymbol{N})$, while transitioning fewer times between compartments $(\boldsymbol{O})$ and having no significant preference for either compartment $(\boldsymbol{P}) . \mathbf{Q}-\boldsymbol{T}$, Female mice showed a similar pattern as the males. Data are presented as mean $\pm \mathrm{SEM}, n=6-10{ }^{*}{ }^{*} p<0.05$, ${ }^{* *} p<0.01$ using within sex two-way ANOVA of genotype (WT vs $\|$ L- $1 \beta^{\text {XAT }}$ ) by treatment (AAV-GFP vs AAV-(re), followed by Tukey's multiple-comparison test. taining $100 \mathrm{~nm}$ 3,4-dihydroxybenzylamine as an internal standard, and stored at $-80^{\circ} \mathrm{C}$. On the day of the HPLC analysis, samples were thawed on ice, sonicated in a bath sonicator (three $5 \mathrm{~s}$ pulses), and centrifuged at $21,000 \times g$ for $20 \mathrm{~min}$ at $0^{\circ} \mathrm{C}$. Thirty microliters of tissue sample were combined with $5 \mu \mathrm{l}$ of ascorbate oxidase $(0.3 \mathrm{mg} / \mathrm{ml})$, and $20 \mu \mathrm{l}$ of this mixture was injected. Samples were injected onto a C18 reverse-phase column $(150 \times 4.6 \mathrm{~mm} ; 5 \mu \mathrm{m}$ particles; ODS, Thermo Electron $)$ by a Waters 717 Plus Autosampler, eluted using an isocratic system with a mobile phase (MD-TM, ESA) containing $1.0 \mathrm{~mm}$ 1-octanesulfonic acid, and pumped by a Waters 515 HPLC pump. Under these conditions, norepinephrine (NE), 5-HT, 5-hydroxyindole-3-acetic acid (5-HIAA), dopamine (DA), 3,4-dihydroxyphenylacetic acid (DOPAC), and homovanillic acid (HVA) were clearly resolved. External standards ranging from 0 to 2 pM were interspersed within the run and the 2 pM standard was injected twice (first and last) to determine whether there had been any drift during the analysis. A Coulochem III electrochemical detector equipped with a 5011A analytical cell (ESA) was used to detect the biogenic amines. Data were captured using the Empower 2 Software system (Waters).

\section{Drug treatment}

To examine the hypothesis that serotonergic hypofunction is a causal factor in the behavioral dysfunction observed following DR neuroinflammation, an acute dose of citalopram (30 mg/kg, i.p.; Abcam), a selective 5-HT reuptake inhibitor (SSRI), was administered $32 \mathrm{~min}$ before testing on the elevated plus-maze. This dose and time course was selected based on the ability to acutely modulate 5-HT levels and affect 5-HTmediated behaviors (Griebel et al., 1994; McEuen et al., 2009; Mombereau et al., 2010), while having no affect on locomotion (Umehara et al., 2013). Our choice of timing was slightly adjusted from the literature (32 min instead of $30 \mathrm{~min}$ before testing) to stagger mice appropriately, allowing for the testing of all animals of one sex to be performed within one test session. Drug was prepared fresh and distributed into syringes before the first injection.

\section{Data analysis and statistics}

Behavioral measures were analyzed within sex by two-way ANOVA (genotype $X$ virus treatment), with Tukey's test used to identify significant post hoc comparisons. Total corticosterone was analyzed within sex by multivariate ANOVA (genotype $\times$ drug treatment $\times$ time). Statistics were performed using JMP8 (SAS) software; data are reported as mean \pm SEM. Microarray data were modeled comparing AAV-GFP versus AAVCre in accordance with behavioral and physiological data using R (version 2.14.2) and the packages arm, bbmle, and limma to fit optical density data to linear models, and estimates for main and interaction effects were determined from these models. Thresholds for multiple comparisons were set at a $q$ value $\leq 0.01$ (Benjamini and Hochberg, 1995). Database for Annotation, Visualization, and Integrated Discovery functional annotation clustering was used for determination of gene clusters that significantly differed between groups. The top five gene clusters are shown in the figure. Heat maps and hierarchical clustering were performed using MultiExperiment Viewer (TM4.org) with Pearson's correlation. HPLC analysis was performed by $t$ test, comparing IL- $1 \beta$ infused with AAV-GFP versus AAV-Cre. Repeated testing on the elevated plus-maze during the citalopram rescue experiment was conducted within sex by two-way ANOVA (treatment $\times$ trial), with post hoc testing comparing citalopram treatment to each of the saline treatments. Significance was set at $p<0.05$.

\section{Results}

IL-1 $\beta$ overexpression within the DR produces a local neuroinflammatory response

We used an IL- $1 \beta^{\mathrm{XAT}}$ mouse (generously provided by M.K. O'Banion, University of Rochester), where chronic IL- $1 \beta$ overexpression is inducible under the control of a glial fibrillary associated protein (GFAP) promoter upon delivery of Cre recombinase. This model allows both spatial and temporal control of IL- $1 \beta$-mediated neuroinflammation. These mice have been previously described as displaying a robust, long-lasting 

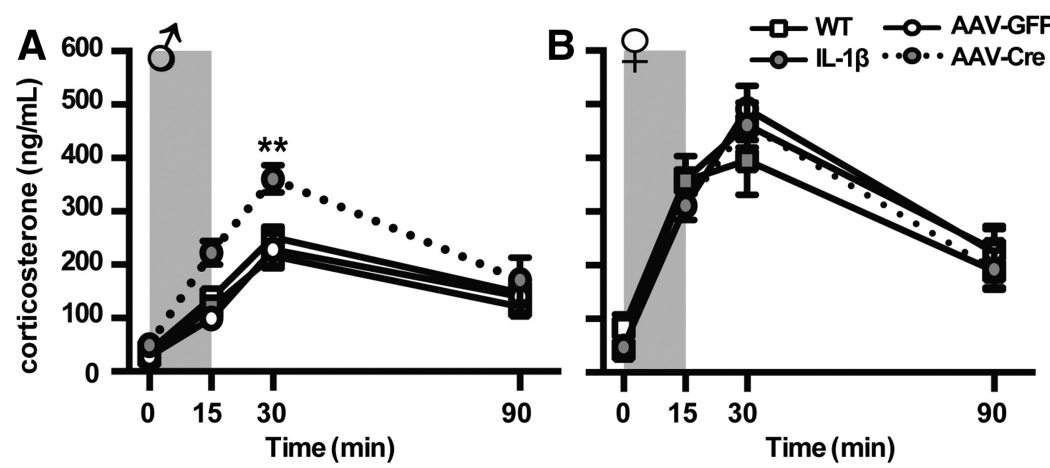

Figure 3. DR neuroinflammation increases male stress responsivity. $\boldsymbol{A}$, Male IL- $1 \beta^{\mathrm{XAT}}$ mice infused with AAV-Cre display an increase in corticosterone production in response to a $15 \mathrm{~min}$ restraint stress (shaded), while exhibiting no difference in baseline or recovery. $\boldsymbol{B}$, No significant effects were observed in females. Data are presented as mean $\pm \mathrm{SEM}, n=9-11,{ }^{* *} p<0.001$ using a within-sex two-way repeated-measures ANOVA comparing genotype (WT vs IL-1 $\beta$ ) vs treatment (AAV-GFP vs AAV-Cre), with time as a repeated measure. Grey bar represents period of 15 min acute restraint stress.
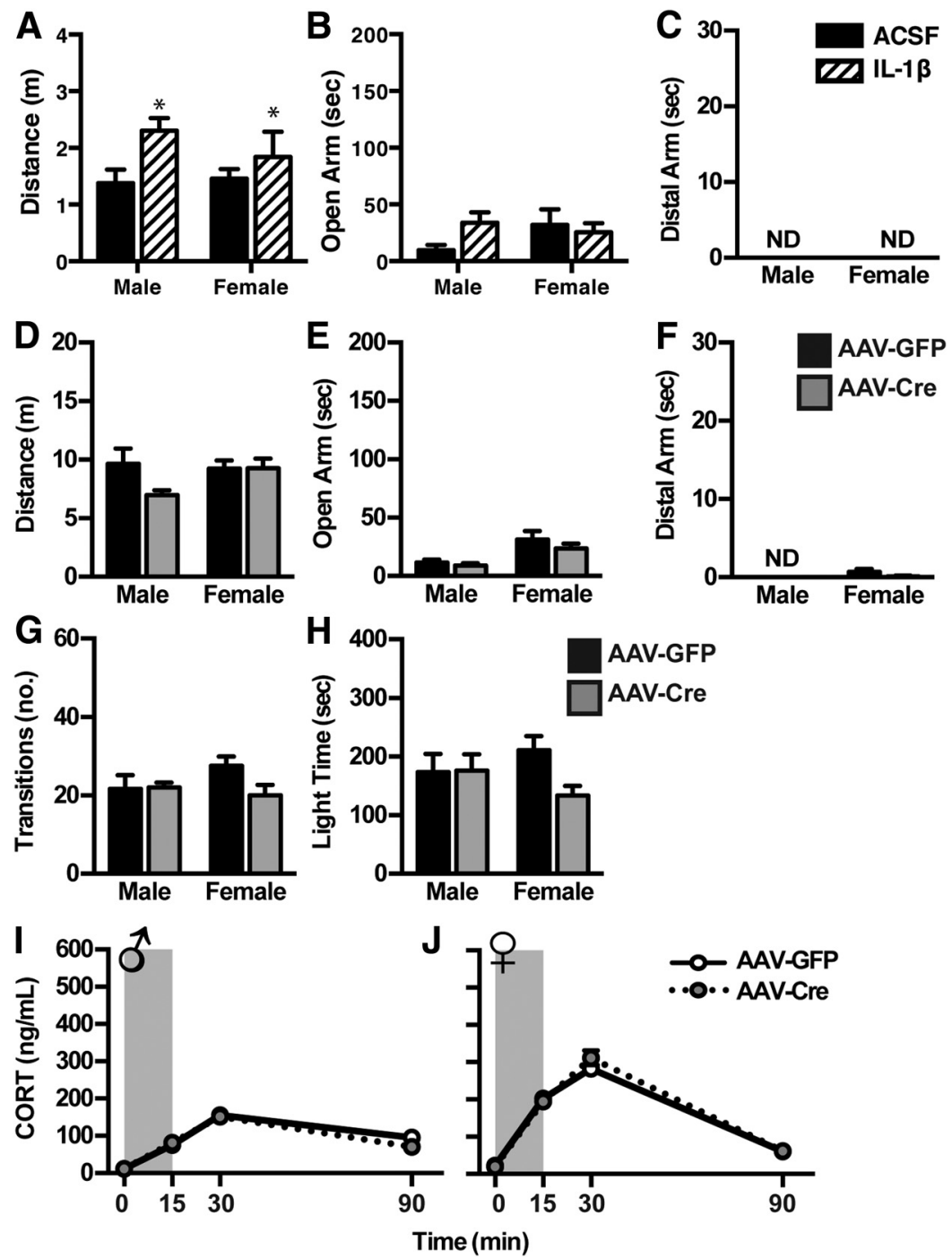

Figure 4. Acute microinfusion of IL-1 $\beta$ into the DR results in increased locomotion but no change in open-arm exploration in the elevated plus-maze. $\boldsymbol{A}-\boldsymbol{C}$, Male and female mice infused with IL-1 $\beta 30 \mathrm{~min}$ before testing on the elevated plus-maze display increased locomotor activity $(\boldsymbol{A})$, but no change in open-arm exploration $(\boldsymbol{B})$. None of the animals traveled to the distal ends of the open arms following DR infusion. PFC neuroinflammation does not induce manic-like behavior or physiology. $\boldsymbol{D}-\boldsymbol{H}$, Male and female IL-1 $\beta^{\text {XAT }}$ mice infused with AAV-Cre showed no difference in behavior on the elevated plus-maze $(\boldsymbol{D}-\boldsymbol{F})$ or light/dark box $(\boldsymbol{G}, \boldsymbol{H}) . \boldsymbol{I}, \boldsymbol{J}$, Neither males $(\boldsymbol{I})$ nor females $(\boldsymbol{J})$ display differences in corticosterone response to an acute 15 min restraint stress (shaded). Data are presented as mean $\pm \mathrm{SEM}, n=7-8$. $^{*} p<0.05$ denotes main effect of infusion following a two-way ANOVA comparing sex versus treatment (AAV-GFP vs AAV-Cre). neuroinflammatory response characterized by increased GFAP expression, microglial ramification, and major histocompatibility complex II expression (Shaftel et al., 2007a,b). Here we show that with a small viral delivery $(0.25 \mu \mathrm{l})$, we are able to induce a neuroinflammatory response that is contained within the DR (Fig. 1). Stereotaxic infusion of an AAV2.5 containing Cre recombinase and GFP (AAV-Cre) into the DR of IL- $1 \beta^{\text {XAT }}$ mice (Fig. 1A) led to spatially restricted LacZ expression (Fig. 1B) and GFP expression (Fig. $1 C$ ), indicating viral transduction within the DR. This resulted in a 1.7 log-fold increase in the IL- $\beta$ transcript within the DR (Fig. $1 D ; F_{(1,24)}=182.2$, $p<0.0001)$. Neither AAV-GFP infusion into IL- $1 \beta^{\mathrm{XAT}}$ mice nor AAV-Cre or AAV-GFP infusion into WT littermates resulted in detectable $\mathrm{LacZ}$ expression (data not shown). In AAV-Cre IL- $1 \beta^{\text {XAT }}$ mice we observed robust microglial activation (Fig. $1 E$ ), as indicated by CD11b expression and ramified morphology of CD11b-immunoreactive cells. We also observed differences in neuronal morphology (NeuN) in AAV-GFP-infused animals (Fig. $1 F$ ) compared with AAVCre-infused animals (Fig. $1 \mathrm{~J}$ ), and profound glial activation, as indicated by robust GFAP and aquaporin-4 immunoreactivity in animals infused with $\mathrm{AAV}$ Cre (Fig. $1 K, L$ ) compared with animals infused with AAV-GFP (Fig. 1G,H). Interestingly, we observed a notable nuclear localization of the tryptophan catabolic enzyme indoleamine 2,3-dioxygenase (IDO) expression in mice infused with AAV-Cre (Fig. $1 M$ ), whereas IDO was undetectable in AAV-GFP animals (Fig. 1I). Importantly, these DR changes were not associated with an increase in circulating IL- $1 \beta$, as measured by $\operatorname{ELISA}\left(F_{(1,29)}=0.4631, p=0.5016\right.$; Fig. $1 N)$.

Raphe neuroinflammation promotes dysregulated stress behavior and physiology

To test the hypothesis that the serotonergic DR is responsible for aspects of neuroinflammation-mediated behavioral dysfunction, animals were behaviorally tested on the elevated plus-maze, light/ dark box, and locobox beginning 5 weeks after viral infusion (Fig. 2). In the elevated plus-maze (Fig. $2 A-F$ ), we detected a significant interaction of genotype (WT vs IL-1 $\beta$ ) and virus (AAV-GFP vs AAVCre), where both male (Fig. $2 A-C$ ) and female (Fig. $2 D-F$ ) IL- $1 \beta$ mice infused with AAV-Cre spent more time in the 


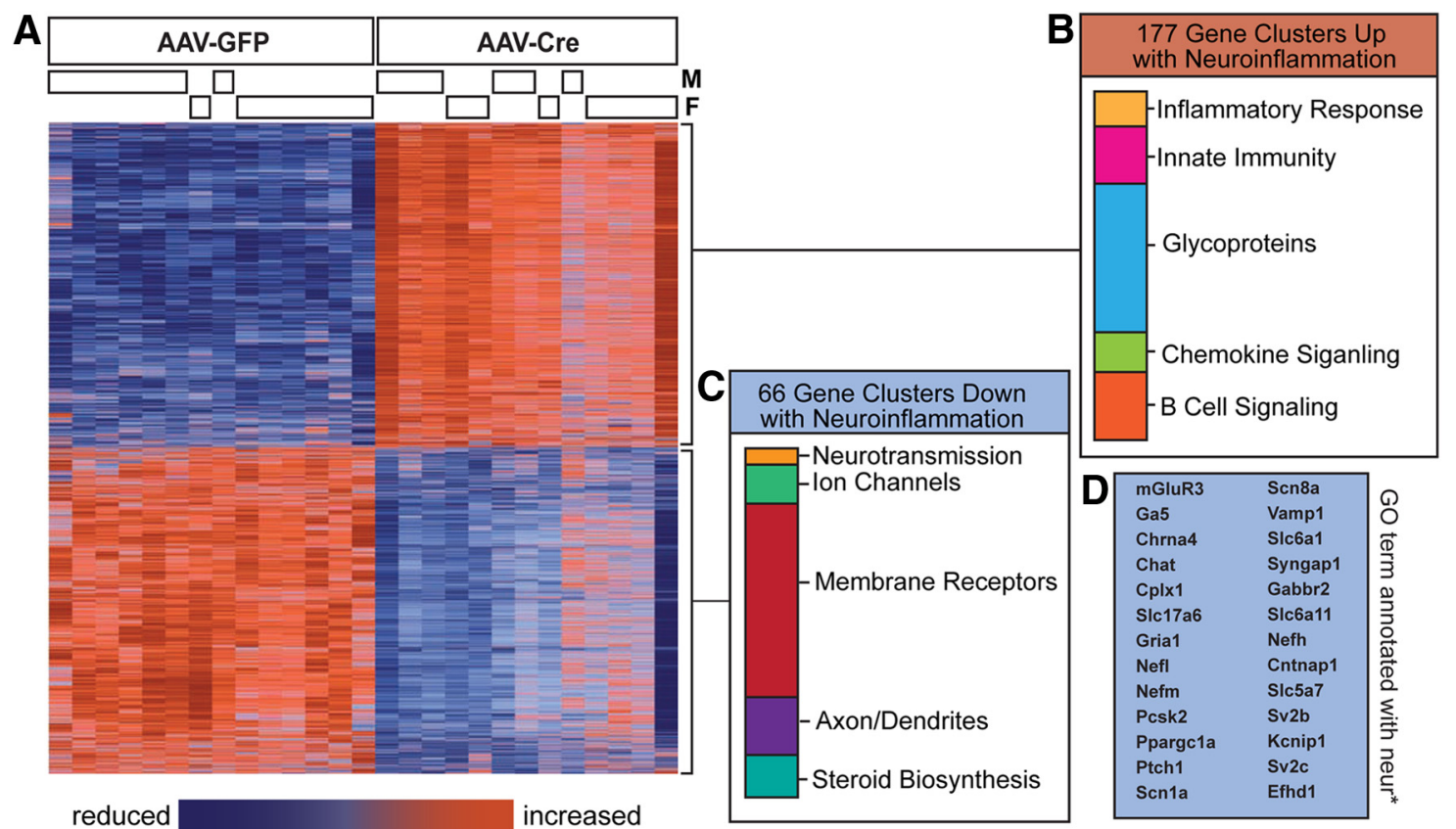

Figure 5. IL-1 $\beta$-mediated neuroinflammation in the DR results in broad changes in gene expression. $A$, Heat map illustrating significant differences in gene expression between AAV-GFP-infused and AAV-Cre-infused male and female DR RNA from IL-1 $\beta^{\mathrm{XAT}}$ mice, where data are expressed as relative levels within each gene, and both animals and genes are organized by hierarchical clustering. $\boldsymbol{B}, \boldsymbol{C}$, Genes that were either significantly upregulated $(\boldsymbol{B})$ or significantly downregulated $(\boldsymbol{C})$, as determined by an false discovery rate of 0.01 , are ranked by enrichment score and organized by functional gene clusters identified using the Database for Annotation, Visualization, and Integrated Discovery bioinformatics database (DAVID). $\boldsymbol{D}$, A separate analysis was performed on genes annotated with the gene ontology term (G0) "neur*," which identified 26 genes that are downregulated in IL-1 $\beta$ animals infused with AAV-Cre.

open $\operatorname{arms}\left(F_{(1,30)}=27.12, p<0.0001 ; F_{(1,24)}=23.08, p<\right.$ 0.0001 ; Fig. $2 B, E)$. In the males, there was a significant effect of genotype $\left(F_{(1,30)}=5.439, p=0.0266\right)$ and virus $\left(F_{(1,30)}=11.44\right.$, $p=0.002)$ on total distance traveled, where IL- $1 \beta$ mice infused with AAV-Cre traveled a greater distance throughout the test than the other groups (Fig. $2 A$ ). In females, this presented as a significant interaction $\left(F_{(1,24)}=8.376, p=0.008\right.$; Fig. $\left.2 D\right)$. Intriguingly, transgenic IL- $1 \beta$ mice infused with AAV-Cre spent a substantial amount of time at the distal ends of the open arms (males: $34.73 \pm 6.8 \mathrm{~s}$; females: $48.40 \pm 15.981 \mathrm{~s}$ ), whereas few of the WT mice or AAV-GFP-infused mice ever entered the distal ends of the open arms (Fig. 2C,F). In the light/dark box (Fig. $2 G-L)$, we detected a significant interaction effect of genotype and virus, where both male (Fig. $2 G-I$ ) and female (Fig. $2 J-L$ ) IL- $1 \beta$ mice infused with AAV-Cre traveled a greater distance when normalized to time spent in the light compartment $\left(F_{(1,27)}\right.$ $=7.525, p=0.011 ; F_{(1,25)}=13.49, p=0.001$; Fig. $\left.2 G, J\right)$ and had a faster speed of travel $\left(F_{(1,27)}=7.607, p=0.010 ; F_{(1,25)}=12.99\right.$, $p=0.0014$; Fig. $2 H-N)$, and spent more time in the light compartment of the box (Fig. $2 I, L)$.

We performed additional testing of novelty-induced locomotion on an additional cohort of IL- $1 \beta$ mice infused with AAVGFP or AAV-Cre in the locobox (Fig. $2 M-T$ ). In this task, where animals were given equal floor space to traverse in an open or narrow compartment, we recapitulated genotype-by-treatment effect on locomotive arousal in both sexes, where males (Fig. $2 M-P)$ showed increased distance traveled $\left(t_{(1,8)}=4.127, p=\right.$ 0.003; Fig. 2M) and females (Fig. 2Q-T) showed the same pattern $\left(t_{(1,9)}=1.909, p=0.088\right)$. Both males and females infused with AAV-Cre displayed increased speed $\left(t_{(1,8)}=4.122, p=\right.$ $\left.0.003 ; t_{(1,9)}=1.915, p=0.089\right)$, while showing no preference toward either the open or narrow compartments.

In our assessment of neuroendocrine stress responsivity, as measured by corticosterone production in response to an acute restraint stress, we found that male IL- $1 \beta$ mice infused with AAV-Cre produced significantly more corticosterone compared with any of the other control groups, displaying a significant interaction effect of genotype by treatment by time $\left(F_{(2,18)}=\right.$ $8.1046, p=0.0014$; Fig. $3 A$ ). Females showed the expected higher corticosterone curve compared with males $\left(F_{(1,40)}=71.345, p<\right.$ $0.0001)$. However, there was no significant interaction of genotype by treatment by time to further increase their corticosterone levels $\left(F_{(2,18)}=0.1243, p=0.9445\right.$; Fig. 3B).

\section{Acute IL-1 $\beta$ infusion affects only locomotion}

We next assessed the impact of an acute IL- $1 \beta$ infusion within the DR to better elucidate the difference between the effects of acute IL- $1 \beta$, and the consequences of chronic IL- $1 \beta$-mediated neuroinflammation, the latter of which being more disease relevant. We found that an acute infusion of IL- $1 \beta$ directly into the DR increased locomotion (Fig. $4 A$ ), as measured by distance traveled throughout the elevated plus-maze $\left(F_{(1,22)}=4.649, p=0.043\right)$, but had no significant effect on time spent in the open arm (Fig. $\left.4 B ; F_{(1,21)}=0.7403, p=0.340\right)$. Further, acute IL- $1 \beta$ failed to elicit the risk-taking behavior of exploration onto the distal ends of the open arms where none of the animals entered the distal ends during the test (Fig. 4C). Of note, all animals in this study had reduced locomotor activity compared with the animals in the transgenic study, likely due to the stress of intracranial infusion $30 \mathrm{~min}$ before behavioral testing. Therefore, as expected, the magnitude of locomotor effects is much smaller than that seen with IL- $1 \beta^{\mathrm{XAT}}$ mice, and none of the mice in this study ventured into the distal ends of the open arms.

\section{The behavioral consequences of neuroinflammation are brain-region specific}

To assess whether the impact of neuroinflammation on behavior is brain-region specific, we performed parallel experiments to 

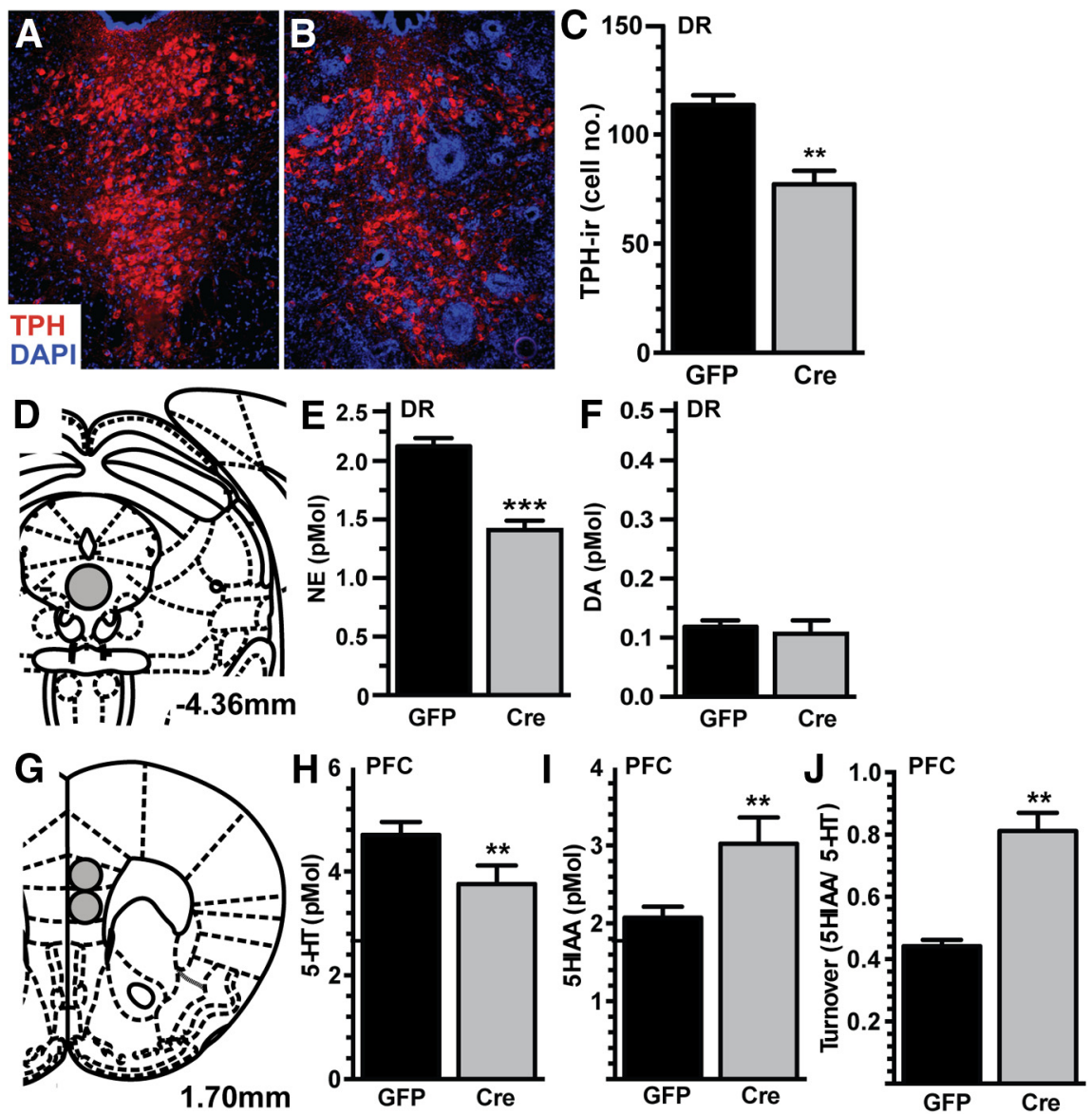

Figure 6. IL-1 $\beta$-mediated neuroinflammation in the DR results in serotonergic hypofunction. $A, B$, Immunofluorescence of TPH-immunoreactivity was used to identify serotonergic neurons (red), counterstained with the nuclear stain DAPI (blue), of AAV-GFP-infused $(\boldsymbol{A})$ and AAV-Cre-infused $(\boldsymbol{B})$ DR 8 weeks following AAV infusion $(n=4)$. $\boldsymbol{C}$, Quantification revealed fewer TPH-immunoreactive cells in AAV-Cre-infused animals. $\boldsymbol{D}-\boldsymbol{F}, \mathrm{HPLC}$ analysis of biogenic amines of the $\mathrm{DR}(\boldsymbol{D})$ revealed less NE $(\boldsymbol{E})$ but no change in DA $(\boldsymbol{F}) . \boldsymbol{G}-\boldsymbol{J}$, In the PFC (G), AAV-Cre-infused animals had less 5-HT $(\boldsymbol{H})$, increased levels of the metabolite $(\boldsymbol{I}, 5$ HIAA), and an overall increase in neurotransmitter turnover (J,5HIAA/5-HT ratio). Data are presented as mean $\pm \mathrm{SEM}, n=6-7 ;{ }^{* *} p<$ $0.01,{ }^{* * *} p<0.0001$ following $t$ test comparing AAV-GFP and AAV-Cre infusion.

induce IL- $1 \beta$ overexpression in the PFC, a region that receives dense serotonergic input, is involved in relevant behaviors, and is also implicated in bipolar disease and schizophrenia (Lewis, 2012; Price and Drevets, 2012; Mann, 2013). When we assessed the behavioral consequences of neuroinflammation in this brain region, we observed no significant effect on behavior or physiology (Fig. 4). Animals performed similarly in the elevated plusmaze, where treatment had no effect on distance traveled $\left(F_{(1,26)}\right.$ $=1.066)$, open-arm time $\left(F_{(1,26)}=1.084\right)$, or distal open-arm entries $\left(F_{(1,23)}=0.8871\right.$; Fig. $\left.4 D-F\right)$. In the light/dark box, treatment did not affect transitions between compartments $\left(F_{(1,26)}=\right.$ $1.748)$ or time spent in the open compartment $\left(F_{(1,25)}=0.01134\right.$; Fig. $4 F-G)$, and no differences in corticosterone response to an acute restraint stress were detected (male: $F_{(1,10)}=0.2317, p=$ 0.6406 ; female: $F_{(1,18)}=0.1243, p=0.9445$; Fig. $\left.4 H, I\right)$.

\section{Changes in gene expression following}

\section{raphe neuroinflammation}

Given the observed behavioral results, we undertook an investigation of the molecular mechanisms that may lead to the increased manic behavior seen with DR neuroinflammation. We performed gene expression profiling studies using microarray to evaluate global change in basal gene expression in the DR of males and females following AAV-GFP or AAV-Cre infusion 2 weeks after the culmination of behavioral testing (Fig. 5; full dataset available through National Center for Biotechnology Information Gene Expression Omnibus repository). We detected robust changes in gene expression, with 4873 genes showing significant differences, as determined by a false discovery rate of 0.01 (Fig. $5 A$ ). Functional annotation clustering of these affected genes with a fold change of $\geq 1$. 1 revealed a significant enrichment for 177 gene clusters (Fig. $5 B$ ), which were primarily involved in inflammatory signaling. This analysis also identified enrichment for the Kyoto Encyclopedia of Genes and Genomes pathway for apoptosis, suggesting some degree of cell death in this brain region. Sixty-six gene clusters were identified as significantly downregulated (Fig. $5 C$ ), the top 20 of which were found to be involved in neurotransmission, ion transport, axon/dendrite morphology and function, and steroid biosynthesis. To identify transcriptional changes that would be most relevant to our hypothesis that neuroinflammation mediates behavioral changes via its effects on neurosignaling within the DR, we conducted a further subanalysis on genes annotated with any gene ontology term containing "neur" to identify genes specifically related to neuron/signaling. This analysis revealed a list of 26 genes corresponding primarily to $5-\mathrm{HT}$, GABA, glutamate, and potassium signaling and transport (Fig. 5D).

\section{DR neuroinflammation results in}

\section{serotonergic hypofunction}

The DR is home to the majority of serotonergic neurons, and we observed changes in behavior indicative of serotonergic dysfunction. Therefore, we investigated the potential changes in the neurochemistry following IL- $1 \beta$ overexpression in a separate cohort of male mice (Fig. 6). We first quantified TPHimmunoreactive neurons within the DR following AAV-GFP or AAV-Cre infusion to assess whether neuroinflammation has the potential to broadly change the population of serotonergic neurons. AAV-Cre-infused animals had significantly fewer TPHimmunoreactive cells in the dorsomedial DR $\left(t_{(1,10)}=4.787, p=\right.$ $0.0007)$ compared with AAV-GFP-infused animals 8 weeks following viral infusion (Fig. $6 A-C$ ). No differences in TPH immunoreactivity were detected in the lateral wing subregions of the $\operatorname{DR}\left(t_{(1,10)}=0.434, p=0.670\right)$, indicating local specificity of these effects. To assess functional consequences, the concentration of NE, DA, and 5-HT and their major metabolites, DOPAC, HVA, and 5-HIAA were measured in the PFC and DR. Within the $\mathrm{DR}$, there was a substantial reduction in $\mathrm{NE}\left(t_{(1,12)}=6.766\right.$, $p<0.0001$; Fig. $6 E)$, with no difference in $\mathrm{DA}\left(t_{(1,12)}=0.492\right.$, $p=0.632$; Fig. $6 F$ ). In the PFC (Fig. $6 G$ ), a major DR output region, there was less 5 -HT $\left(t_{(1,11)}=2.232, p=0.047\right.$; Fig. $6 H)$, more 5-HIAA $\left(t_{(1,11)}=2.748, p=0.019\right.$; Fig. $\left.6 I\right)$, and greater turnover $\left(t_{(1,11)}=6.368, p<0.0001\right.$; Fig. $\left.6 J\right)$. No 
significant differences were found in NE or DA in the PFC (data not shown).

Acute citalopram treatment ameliorates behavioral dysfunction following IL$1 \beta$-induced neuroinflammation in the DR

To test the hypothesis that the observed behavioral dysfunction was the result of an inadequate pool of available 5-HT during the acute behavioral testing, we next assessed whether pharmacological elevation in 5-HT would rescue the behavioral phenotype caused by DR neuroinflammation. To do this, male and female mice were repeatedly tested on the elevated plus-maze following intraperitoneal injection of $30 \mathrm{mg} / \mathrm{kg}$ citalopram to acutely elevate 5-HT levels (Fig. 7). As observed in previous cohorts, saline-injected AAVCre-infused animals had an increase in total distance traveled throughout the test $\left(F_{(1,7)}=14.13, p=0.0071\right.$; Fig. $\left.7 A, C\right)$, and spent significantly more time exploring the open arms of the maze $\left(F_{(1,7)}=\right.$ 26.87, $p=0.0013$; Fig. $7 B, E)$ and the distal ends of the open arms $\left(F_{(1,7)}=18.18, p=0.0037\right.$; Fig. $\left.7 C, F\right)$. Repeated-measures ANOVA revealed a significant interaction effect of citalopram treatment to ameliorate open-arm time $\left(F_{(2,14)}\right.$ $=4.380, p=0.0333)$, distance traveled $\left(F_{(2,14)}=8.557, p=\right.$ $0.0037)$, and end of open-arm entries $\left(F_{(2,14)}=5.168, p=\right.$ 0.0186 ) in AAV-Cre-infused male IL- $1 \beta$ mice (Fig. $7 A-C$ ). Females showed the same pattern in all measures, with significance reached in measures of open-arm time $\left(F_{(2,12)}=6.359, p=\right.$ 0.0131; Fig. 7D-F). Post hoc testing in these parameters indicated significant difference of saline treatment (Test 1 and 3) from citalopram treatment (Test 2), indicating the citalopram effect was not one of repeated testing. IL- $1 \beta$ mice infused with AAVGFP showed decreased exploration over repeated testing, as expected, with no effect of citalopram administration.

\section{Discussion}

Impulsivity, risk-taking behavior, and elevated stress responsivity are prominent symptoms of mania, a state of hyperarousal common to schizophrenia, bipolar disorder, and other psychotic illnesses. Epidemiological evidence suggests that inflammation within the brain plays a role in the pathophysiology of these diseases (Najjar et al., 2013). However, the mechanistic link between neuroinflammation and the development of manic-like behavior remains unknown, though likely involves 5-HT, which plays a central role in modulating relevant behaviors. Through the use of an IL- $1 \beta^{\mathrm{XAT}}$ transgenic model of brain region-specific neuroinflammation, we tested the hypothesis that neuroinflammation within the serotonergic DR is able to recapitulate aspects of manic-like behavior.

The manic-like phenotypes that we observed following IL- $1 \beta$ mediated neuroinflammation in the DR were striking, reminiscent of recently defined examples of manic-like behavior in mouse models (Han et al., 2013; Saul et al., 2013; Kirshenbaum et al., 2014). Here we show that across several behavioral paradigms, animals displayed increased novelty-induced locomotion and a disinhibited exploration of adverse environments (e.g., distal ends of the open arm in the elevated plus-maze). While addi-
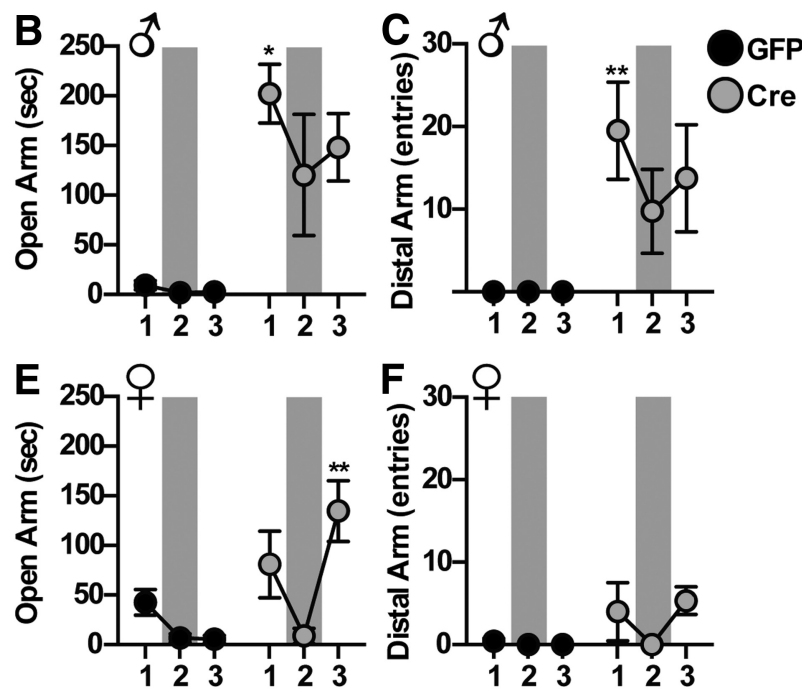

Figure 7. Acute increase in 5-HT ameliorates manic-like phenotype in the elevated plus-maze. IL-1 $\beta^{\mathrm{XAT}}$ mice were infused with AAV-GFP or AAV-Cre into the DR and tested for 3 consecutive weeks on the elevated plus-maze 32 min after intraperitoneal (Tests 1, 3) or $30 \mathrm{mg} / \mathrm{kg}$ citalopram (Test 2, shaded). $\boldsymbol{A}-\boldsymbol{C}$, Male mice infused with AAV-Cre show a significan es show a similar pattern of behavior. Data are presented as mean \pm SEM, $n=4-5,{ }^{*} p<0.05,{ }^{* *} p<0.01$ following two-way ANOVA of treatment by trial. Post hoc test compared citalopram to each saline treatment.

tional behavioral tests assessing changes in sleep, circadian rhythms, and reward value would need to be conducted to fully determine whether these mice display a complete profile reminiscent of the complex state of human mania, these features, coupled with the observed increase in neuroendocrine stress responsivity, closely resemble the behavioral and physiological dysregulation observed in schizophrenia and bipolar disorder. Patients with schizophrenia, for example, exhibit emotional overarousal to neutral social scenes (Haralanova et al., 2012), engage in risky sexual behavior associated with a higher incidence of sexually transmitted infections (Ramrakha et al., 2000), and present with exacerbated symptoms in the face of stress exposure (Jones and Fernyhough, 2007). Patients with bipolar disorder, as well, show increased exploration and novelty seeking (Minassian et al., 2011), engage in high-risk behaviors, such as gambling (Chandler et al., 2009), and exhibit a hyperactive neuroendocrine response to stress (Watson et al., 2004). The effects we observed appear to be mediated by the neuroinflammation following IL$1 \beta$, overexression as an acute administration of the cytokine directly into the DR did not impact these aspects of manic-like behavior. Serotonergic cell bodies within the DR play a central role in the regulation of the behavioral features of mania (Homberg and Lesch, 2011; Bortolato et al., 2013). Thus, the observed changes in behavior are highly suggestive of a recapitulation of neuroinflammation-induced mania in an animal model that may be driven by alterations to the serotonergic system.

We predicted an anatomical specificity to the effects, and tested this hypothesis by conducting parallel experiments targeting the PFC, which receives dense serotonergic input from the $\mathrm{DR}$, and thus is an important downstream mediator of the behavioral effects of 5-HT. Five-HT signaling within the PFC is critical for impulse control and cognitive flexibility, where depletion results in capricious and perseverative behavior (Clarke et al., 2004). Indeed, there is evidence for reduced 5-HT in the PFC of patients with schizophrenia (Sumiyoshi et al., 2013). Neuroinflammation localized to this key serotonergic output region was insufficient to alter behavior, suggesting that inflammatory 
signals alter 5-HT-mediated behavior via effects on the serotonergic cell bodies at the level of the DR.

Therefore, we next evaluated the impact of our manipulations on gene expression within the DR, focusing both on broad programmatic changes, as well as those of particular relevance to neurotransmission and serotonergic signaling. The microarray revealed a predicted increase in inflammation-related genes, consistent with our immunofluorescent characterization of the model. More interestingly, genes related to 5-HT, GABA, glutamate, and noradrenergic neurotransmitter systems were profoundly decreased in the DR, suggesting dramatically altered neuronal excitability, synaptic transmission, and ability to adapt to external input. This imbalance is consistent with the ability of IL- $1 \beta$ to directly inhibit spontaneous serotonergic neuron firing in vitro (Manfridi et al., 2003). Additionally, IL- $1 \beta$ has recently been shown to play a role in modulating glutamate transmission in the experimental autoimmune encephalomyelitis model of multiple sclerosis (Mandolesi et al., 2013), supporting the ability for IL-1 $\beta$ to modulate neurotransmission and regulate serotonergic neuron excitability and output.

Based on the directionality of transcriptional changes, we hypothesized that there may be fewer 5-HT-producing neurons within the DR. This was confirmed immunohistochemically, where we observed a $30 \%$ reduction in overall TPH-immunoreactive neurons. This may be the result of a downregulation of TPH itself (i.e., reduced detection of TPH immunoreactivity), or to a loss of serotonergic neurons. In the same animals, HPLC analysis revealed reduced 5-HT output to the PFC. While 5-HT was measured in the PFC as one readout of DR serotonergic output, this is likely predictive of a brain-wide reduction in 5-HT. Interestingly, DR lesions have previously been shown to increase exploration in the open arm of the elevated plus-maze, consistent with our findings of serotonergic hypofunction and an increase in apoptosis-related gene expression in the DR (Briley et al., 1990). Therefore, the effect of neuroinflammation within the DR could be due to reduced serotonergic responsivity, neuron number, or ability to produce 5-HT.

To further test this hypothesis, we used a pharmacological strategy to rescue the phenotype of these mice by treatment with the SSRI, citalopram, to rapidly increase 5-HT availability. We found that a single dose of citalopram ameliorated the behavioral dysfunction of IL- $1 \beta$ mice infused with AAV-Cre on the elevated plus-maze. These animals spent less time in the open arm, had fewer visits to the end of the open arm, and had an overall reduction in hyperlocomotion compared with their original performance 1 week earlier. Importantly, when animals were retested again following vehicle treatment, the direction of their behavior returned toward a dysregulated state. The transient rescue of behavior demonstrates that reduced 5-HT does indeed play a causal role in the manic-like behavior observed following DR neuroinflammation. However, as behavior was not restored completely to control levels, it is also possible that having fewer 5-HTproducing neurons could have reduced the effectiveness of the drug to raise 5-HT levels sufficiently and/or that an acute increase in available 5-HT does not completely compensate for the chronic dysregulation within the DR.

One possible coexisting mechanism that could contribute to the observed behavioral dysfunction is an increase in lipocalin-2 ( $\operatorname{Lcn} 2)$, a suggestion that is supported by our microarray dataset in which Lcn2 displayed a $2.5 \log$-fold increase in expression. Lcn2, an iron-binding sideophore, is commonly increased in response to inflammatory insult due to its ability to deprive bacteria of necessary iron. Thus, it serves as an important protective role in the case of bacterial infiltration. Pathological consequences of Lcn2 upregulation, however, are substantial. TPH, the ratelimiting enzyme in the synthesis of 5-HT, requires iron for proper enzymatic activity (Nakata and Fujisawa, 1982a, b). Therefore, Lcn2-mediated deprivation of iron could result in an inability to synthesize 5-HT (Bachman et al., 2009). Additionally, Lcn2 has the ability to reduce the bioavailability of catecholamines, as sequestration of iron occurs through binding available catechol groups (Bao et al., 2010; Miethke and Skerra, 2010). In the brain, maintaining appropriate levels of catecholamines, which include $\mathrm{NE}$ and DA, is vitally important to behavioral homeostasis. In the DR, specifically, noradrenergic input from the locus ceruleus exerts tonic control on 5-HT neurons to increase serotonergic tone (Baraban and Aghajanian, 1980, 1981; Vandermaelen and Aghajanian, 1983; Pan et al., 1994). Therefore, our measured reduction of NE in the DR could be indicative of insufficient NE, which has been shown to result in reduced serotonergic neuron firing and less 5-HT release in target brain regions (Pudovkina et al., 2002). Inflammation-induced serotonergic hypofunction could be partly explained by the observed elevation in Lcn2, and consequent reduced TPH functioning and/or NE in the DR.

Our findings of a 5-HT-mediated manic phenotype raise an important question: how can serotonergic hypofunction result in both manic and depressive-like behavior? Most reports of the association between neuroinflammation and neuropsychiatric disease have focused on the depressive aspects of disease, such as "sickness behavior" following immune activation, or symptoms of depression in patients with rheumatoid arthritis, in patients with multiple sclerosis, or in patients following IFN $\gamma$ treatment. Furthermore, SSRIs, which increase 5-HT availability, treat symptoms of depression in many patients, thus suggesting a connection between reduced 5-HT and depression. However, substantial evidence also links the 5-HT system to manic behavior. 5 -HT is known to regulate hedonic, aggressive, and risk-taking behavior, all aspects of human mania (Jones and Fernyhough, 2007; Chandler et al., 2009; Minassian et al., 2011; Haralanova et al., 2012). Interestingly, a recent study reported an association between immune activation and manic symptoms in patients with depressive disorders (Becking et al., 2013), helping to link the seemingly conflicting epidemiological evidence. Indeed, the prevalence of subthreshold manic symptoms is $\sim 40 \%$ in patients with unipolar depression (Zimmermann et al., 2009; Angst et al., 2010), suggesting that these disorders may be part of a spectrum with potentially overlapping etiology.

In summary, our findings demonstrate a profound ability for localized inflammation in the DR to induce manic-like symptoms, which were associated with neurotransmitter imbalance within the DR. The complex state of human mania includes disturbances in sleep, circadian rhythms, and reward value. These findings support the hypothesis that neuroinflammation may be a key etiological component in the development of mania, and further demonstrate that the DR is a critical brain region mediating these behavioral outcomes. These findings implicate dysregulation of 5-HT signaling as important mediators of the effects of neuroinflammation on behavior.

\section{References}

Alvarado-Esquivel C, Sánchez-Anguiano LF, Arnaud-Gil CA, LópezLongoria JC, Molina-Espinoza LF, Estrada-Martínez S, Liesenfeld O, Hernández-Tinoco J, Sifuentes-Álvarez A, Salas-Martínez C (2013) Toxoplasma gondii infection and suicide attempts: a case-control study in psychiatric outpatients. J Nerv Ment Dis 201:948-952. CrossRef Medline Angst J, Cui L, Swendsen J, Rothen S, Cravchik A, Kessler RC, Merikangas KR 
(2010) Major depressive disorder with subthreshold bipolarity in the National Comorbidity Survey Replication. Am J Psychiatry 167:11941201. CrossRef Medline

Bachman MA, Miller VL, Weiser JN (2009) Mucosal lipocalin 2 has proinflammatory and iron-sequestering effects in response to bacterial enterobactin. PLoS Pathog 5:e1000622. CrossRef Medline

Bao G, Clifton M, Hoette TM, Mori K, Deng SX, Qiu A, Viltard M, Williams D, Paragas N, Leete T, Kulkarni R, Li X, Lee B, Kalandadze A, Ratner AJ, Pizarro JC, Schmidt-Ott KM, Landry DW, Raymond KN, Strong RKet al. (2010) Iron traffics in circulation bound to a siderocalin (Ngal)-catechol complex. Nat Chem Biol 6:602-609. CrossRef Medline

Baraban JM, Aghajanian GK (1980) Suppression of firing activity of 5-HT neurons in the dorsal raphe by alpha-adrenoceptor antagonists. Neuropharmacology 19:355-363. CrossRef Medline

Baraban JM, Aghajanian GK (1981) Noradrenergic innervation of serotonergic neurons in the dorsal raphe: demonstration by electron microscopic autoradiography. Brain Res 204:1-11. CrossRef Medline

Barrientos RM, Hein AM, Frank MG, Watkins LR, Maier SF (2012) Intracisternal interleukin-1 receptor antagonist prevents postoperative cognitive decline and neuroinflammatory response in aged rats. J Neurosci 32:14641-14648. CrossRef Medline

Becking K, Boschloo L, Vogelzangs N, Haarman BC, Riemersma-van der Lek R, Penninx BW, Schoevers RA (2013) The association between immune activation and manic symptoms in patients with a depressive disorder. Transl Psychiatry 3:e314. CrossRef Medline

Benjamini Y, Hochberg Y (1995) Controlling the false discovery rate: a practical and powerful approach to multiple testing. J R Stat Soc Series B Stat Methodol 57:289-300.

Bortolato M, Pivac N, Muck Seler D, Nikolac Perkovic M, Pessia M, Di Giovanni G (2013) The role of the serotonergic system at the interface of aggression and suicide. Neuroscience 236:160-185. CrossRef Medline

Briley M, Chopin P, Moret C (1990) Effect of serotonergic lesion on "anxious" behaviour measured in the elevated plus-maze test in the rat. Psychopharmacology (Berl) 101:187-189. CrossRef Medline

Bruce TO (2008) Comorbid depression in rheumatoid arthritis: pathophysiology and clinical implications. Curr Psychiatry Rep 10:258-264. CrossRef Medline

Chandler RA, Wakeley J, Goodwin GM, Rogers RD (2009) Altered riskaversion and risk-seeking behavior in bipolar disorder. Biol Psychiatry 66:840-846. CrossRef Medline

Clarke HF, Dalley JW, Crofts HS, Robbins TW, Roberts AC (2004) Cognitive inflexibility after prefrontal serotonin depletion. Science 304:878880. CrossRef Medline

Crockett MJ, Clark L, Hauser MD, Robbins TW (2010) Serotonin selectively influences moral judgment and behavior through effects on harm aversion. Proc Natl Acad Sci U S A 107:17433-17438. CrossRef Medline

Dantzer R, O'Connor JC, Freund GG, Johnson RW, Kelley KW (2008) From inflammation to sickness and depression: when the immune system subjugates the brain. Nat Rev Neurosci 9:46-56. CrossRef Medline

de Vries HE, Kuiper J, de Boer AG, Van Berkel TJ, Breimer DD (1997) The blood-brain barrier in neuroinflammatory diseases. Pharmacol Rev 49: 143-155. Medline

Gerber AR, Bale TL (2012) Antiinflammatory treatment ameliorates HPA stress axis dysfunction in a mouse model of stress sensitivity. Endocrinology 153:4830-4837. CrossRef Medline

Griebel G, Moreau JL, Jenck F, Misslin R, Martin JR (1994) Acute and chronic treatment with 5-HT reuptake inhibitors differentially modulate emotional responses in anxiety models in rodents. Psychopharmacology (Berl) 113:463-470. CrossRef Medline

Han K, Holder JL Jr, Schaaf CP, Lu H, Chen H, Kang H, Tang J, Wu Z, Hao S, Cheung SW, Yu P, Sun H, Breman AM, Patel A, Lu HC, Zoghbi HY (2013) SHANK3 overexpression causes manic-like behaviour with unique pharmacogenetic properties. Nature 503:72-77. CrossRef Medline

Haralanova E, Haralanov S, Beraldi A, Möller HJ, Hennig-Fast K (2012) Subjective emotional over-arousal to neutral social scenes in paranoid schizophrenia. Eur Arch Psychiatry Clin Neurosci 262:59-68. CrossRef Medline

Hayley S, Scharf J, Anisman H (2013) Central administration of murine interferon-alpha induces depressive-like behavioral, brain cytokine and neurochemical alterations in mice: a mini-review and original experiments. Brain Behav Immun 31:115-127. CrossRef Medline
Hein AM, Stasko MR, Matousek SB, Scott-McKean JJ, Maier SF, Olschowka JA, Costa AC, O'Banion MK (2010) Sustained hippocampal IL-1beta overexpression impairs contextual and spatial memory in transgenic mice. Brain Behav Immun 24:243-253. CrossRef Medline

Homberg JR, Lesch KP (2011) Looking on the bright side of serotonin transporter gene variation. Biol Psychiatry 69:513-519. CrossRef Medline

Howerton AR, Roland AV, Fluharty JM, Marshall A, Chen A, Daniels D, Beck SG, Bale TL (2013) Sex differences in corticotropin-releasing factor receptor-1 action within the dorsal raphe nucleus in stress responsivity. Biol Psychiatry pii:S0006-3223(13)00948-7. CrossRef Medline

Huang Y, Henry CJ, Dantzer R, Johnson RW, Godbout JP (2008) Exaggerated sickness behavior and brain proinflammatory cytokine expression in aged mice in response to intracerebroventricular lipopolysaccharide. Neurobiol Aging 29:1744-1753. CrossRef Medline

Ingram WM, Goodrich LM, Robey EA, Eisen MB (2013) Mice infected with low-virulence strains of Toxoplasma gondii lose their innate aversion to cat urine, even after extensive parasite clearance. PLoS One 8:e75246. CrossRef Medline

Jones SR, Fernyhough C (2007) A new look at the neural diathesis-stress model of schizophrenia: the primacy of social-evaluative and uncontrollable situations. Schizophr Bull 33:1171-1177. CrossRef Medline

Kirshenbaum GS, Burgess CR, Déry N, Fahnestock M, Peever JH, Roder JC (2014) Attenuation of mania-like behavior in Na, K-ATPase alpha3 mutant mice by prospective therapies for bipolar disorder: melatonin and exercise. Neuroscience 260:195-204. CrossRef Medline

Koerber JT, Klimczak R, Jang JH, Dalkara D, Flannery JG, Schaffer DV (2009) Molecular evolution of adeno-associated virus for enhanced glial gene delivery. Mol Ther 17:2088-2095. CrossRef Medline

Kwentus JA, Hart RP, Calabrese V, Hekmati A (1986) Mania as a symptom of multiple sclerosis. Psychosomatics 27:729-731. CrossRef Medline

Lewis DA (2012) Cortical circuit dysfunction and cognitive deficits in schizophrenia-implications for preemptive interventions. Eur J Neurosci 35:1871-1878. CrossRef Medline

Mandolesi G, Musella A, Gentile A, Grasselli G, Haji N, Sepman H, Fresegna D, Bullitta S, De Vito F, Musumeci G, Di Sanza C, Strata P, Centonze D (2013) Interleukin-1 $\beta$ alters glutamate transmission at purkinje cell synapses in a mouse model of multiple sclerosis. J Neurosci 33:12105-12121. CrossRef Medline

Manfridi A, Brambilla D, Bianchi S, Mariotti M, Opp MR, Imeri L (2003) Interleukin-1beta enhances non-rapid eye movement sleep when microinjected into the dorsal raphe nucleus and inhibits serotonergic neurons in vitro. Eur J Neurosci 18:1041-1049. CrossRef Medline

Mann JJ (2013) The serotonergic system in mood disorders and suicidal behaviour. Philos Trans R Soc Lond B Biol Sci 368:20120537. CrossRef Medline

McEuen JG, Beck SG, Bale TL (2008) Failure to mount adaptive responses to stress results in dysregulation and cell death in the midbrain raphe. J Neurosci 28:8169-8177. CrossRef Medline

McEuen JG, Semsar KA, Lim MA, Bale TL (2009) Influence of sex and corticotropin-releasing factor pathways as determinants in serotonin sensitivity. Endocrinology 150:3709-3716. CrossRef Medline

Meszaros ZS, Perl A, Faraone SV (2012) Psychiatric symptoms in systemic lupus erythematosus: a systematic review. J Clin Psychiatry 73:993-1001. CrossRef Medline

Miethke M, Skerra A (2010) Neutrophil gelatinase-associated lipocalin expresses antimicrobial activity by interfering with L-norepinephrinemediated bacterial iron acquisition. Antimicrob Agents Chemother 54: 1580-1589. CrossRef Medline

Minassian A, Henry BL, Young JW, Masten V, Geyer MA, Perry W (2011) Repeated assessment of exploration and novelty seeking in the human behavioral pattern monitor in bipolar disorder patients and healthy individuals. PLoS One 6:e24185. CrossRef Medline

Modabbernia A, Taslimi S, Brietzke E, Ashrafi M (2013) Cytokine alterations in bipolar disorder: a meta-analysis of 30 studies. Biol Psychiatry 74:15-25. CrossRef Medline

Mombereau C, Gur TL, Onksen J, Blendy JA (2010) Differential effects of acute and repeated citalopram in mouse models of anxiety and depression. Int J Neuropsychopharmacol 13:321-334. CrossRef Medline

Müller N, Myint AM, Schwarz MJ (2009) The impact of neuroimmune dysregulation on neuroprotection and neurotoxicity in psychiatric disorders-relation to drug treatment. Dialogues Clin Neurosci 11:319-332. Medline 
Najjar S, Pearlman DM, Alper K, Najjar A, Devinsky O (2013) Neuroinflammation and psychiatric illness. J Neuroinflammation 10:43. CrossRef Medline

Nakata H, Fujisawa H (1982a) Purification and properties of tryptophan 5-monooxygenase from rat brain-stem. Eur J Biochem 122:41-47. CrossRef Medline

Nakata H, Fujisawa H (1982b) Tryptophan 5-monooxygenase from mouse mastocytoma P815. A simple purification and general properties. Eur J Biochem 124:595-601. Medline

Pan ZZ, Grudt TJ, Williams JT (1994) Alpha 1-adrenoceptors in rat dorsal raphe neurons: regulation of two potassium conductances. J Physiol 478: 437-447. Medline

Paxinos G, Franklin KBJ (2001) The mouse brain in stereotaxic coordinates, 2nd edition. San Diego: Academic.

Price JL, Drevets WC (2012) Neural circuits underlying the pathophysiology of mood disorders. Trends Cogn Sci 16:61-71. CrossRef Medline

Pudovkina OL, Cremers TI, Westerink BH (2002) The interaction between the locus coeruleus and dorsal raphe nucleus studied with dual-probe microdialysis. Eur J Pharmacol 445:37-42. CrossRef Medline

Ramrakha S, Caspi A, Dickson N, Moffitt TE, Paul C (2000) Psychiatric disorders and risky sexual behaviour in young adulthood: cross sectional study in birth cohort. BMJ 321:263-266. CrossRef Medline

Rosenfeld MR, Dalmau J (2011) Anti-NMDA-receptor encephalitis and other synaptic autoimmune disorders. Curr Treat Options Neurol 13: 324-332. CrossRef Medline

Saul MC, Stevenson SA, Gammie SC (2013) Sexually dimorphic, developmental, and chronobiological behavioral profiles of a mouse mania model. PLoS One 8:e72125. CrossRef Medline

Shaftel SS, Kyrkanides S, Olschowka JA, Miller JN, Johnson RE, O’Banion MK (2007a) Sustained hippocampal IL-1 beta overexpression mediates chronic neuroinflammation and ameliorates Alzheimer plaque pathology. J Clin Invest 117:1595-1604. CrossRef Medline

Shaftel SS, Carlson TJ, Olschowka JA, Kyrkanides S, Matousek SB, O’Banion MK (2007b) Chronic interleukin-1 $\beta$ expression in mouse brain leads to leukocyte infiltration and neutrophil-independent blood-brain barrier permeability without overt neurodegeneration. J Neurosci 27:9301-9309. CrossRef Medline

Shiah IS, Yatham LN (2000) Serotonin in mania and in the mechanism of action of mood stabilizers: a review of clinical studies. Bipolar Disord 2:77-92. CrossRef Medline

Song C, Horrobin DF, Leonard BE (2006) The comparison of changes in behavior, neurochemistry, endocrine, and immune functions after different routes, doses and durations of administrations of IL-1beta in rats. Pharmacopsychiatry 39:88-99. CrossRef Medline

Stein JM, Bergman W, Fang Y, Davison L, Brensinger C, Robinson MB, Hecht NB, Abel T (2006) Behavioral and neurochemical alterations in mice lacking the RNA-binding protein translin. J Neurosci 26:2184-2196. CrossRef Medline

Sumiyoshi T, Higuchi Y, Uehara T (2013) Neural basis for the ability of atypical antipsychotic drugs to improve cognition in schizophrenia. Front Behav Neurosci 7:140. CrossRef Medline

Takahashi A, Shimamoto A, Boyson CO, DeBold JF, Miczek KA (2010) $\mathrm{GABA}(\mathrm{B})$ receptor modulation of serotonin neurons in the dorsal raphe nucleus and escalation of aggression in mice. J Neurosci 30:11771-11780. CrossRef Medline

Umehara M, Ago Y, Fujita K, Hiramatsu N, Takuma K, Matsuda T (2013) Effects of serotonin-norepinephrine reuptake inhibitors on locomotion and prefrontal monoamine release in spontaneously hypertensive rats. Eur J Pharmacol 702:250-257. CrossRef Medline

Vandermaelen CP, Aghajanian GK (1983) Electrophysiological and pharmacological characterization of serotonergic dorsal raphe neurons recorded extracellularly and intracellularly in rat brain slices. Brain Res 289:109-119. CrossRef Medline

Watson S, Gallagher P, Ritchie JC, Ferrier IN, Young AH (2004) Hypothalamic-pituitary-adrenal axis function in patients with bipolar disorder. Br J Psychiatry 184:496-502. CrossRef Medline

Webster JP, Kaushik M, Bristow GC, McConkey GA (2013) Toxoplasma gondii infection, from predation to schizophrenia: can animal behaviour help us understand human behaviour? J Exp Biol 216:99-112. CrossRef Medline

Zhu CB, Blakely RD, Hewlett WA (2006) The proinflammatory cytokines interleukin-1beta and tumor necrosis factor-alpha activate serotonin transporters. Neuropsychopharmacology 31:2121-2131. Medline

Zimmermann P, Brückl T, Nocon A, Pfister H, Lieb R, Wittchen HU, Holsboer F, Angst J (2009) Heterogeneity of DSM-IV major depressive disorder as a consequence of subthreshold bipolarity. Arch Gen Psychiatry 66:1341-1352. CrossRef Medline 